\title{
Antitumor activities of dFv-LDP-AE: An enediyne-energized fusion protein targeting tumor-associated antigen gelatinases
}

\author{
GEN-SHEN ZHONG ${ }^{1}$, MIN-NA WU ${ }^{2}$, XIAO-FANG GUO ${ }^{2}$, \\ SHENG-HUA ZHANG ${ }^{3}$, QING-FANG MIAO ${ }^{3}$ and YONG-SU ZHEN ${ }^{3}$ \\ ${ }^{1}$ The First Affiliated Hospital of Xinxiang Medical University, Xinxiang, Henan Province 453100; \\ ${ }^{2}$ Xinxiang Medical University, Xinxiang, Henan Province 453003; ${ }^{3}$ Institute of Medicinal Biotechnology, \\ Chinese Academy of Medical Sciences and Peking Union Medical College, Beijing 100050, P.R. China
}

Received March 21, 2012; Accepted June 5, 2012

DOI: $10.3892 / o r .2012 .1910$

\begin{abstract}
Gelatinases play an important role in tumor growth and metastasis, and overexpression of these molecules is strongly correlated with poor prognosis in a variety of malignant tumors. Lidamycin is an enediyne antitumor antibiotic with potent cytotoxicity. We previously reported that a tandem $\mathrm{scFv}$ format (dFv-LDP-AE) showed enhanced binding ability with gelatinases compared with the scFv-lidamycin conjugate (Fv-LDP-AE). In this study, the antitumor activities of dFv-LDP-AE on hepatocellular carcinoma (HCC) were evaluated in vitro and in vivo. By SDS-PAGE analysis, it was found that partial fusion protein $\mathrm{dFv}$-LDP existed as dimer; the results of ELISA and immunofluorescence demonstrated that the fusion protein $\mathrm{dFv}$-LDP could efficiently bind to hepatoma cells in vitro. The apparent arrest of cell cycle at $\mathrm{G} 2 / \mathrm{M}$ phase and induction of apoptosis at nanomole levels indicated that the $\mathrm{dFv}$-LDP-AE was very potent against HCC. In in vivo experiments, $\mathrm{dFv}-\mathrm{LDP}-\mathrm{AE}$ shown enhanced cytotoxic effects compared to those of LDM. Administration at mouse tolerable dosage level, the inhibition rate of tumor growth was $89.5 \%$ of $\mathrm{dFv}-\mathrm{LDP}-\mathrm{AE}$ vs. $73.6 \%$ of LDM on transplantable $\mathrm{H} 22$ in mice $(\mathrm{P}<0.05)$ and, $87.3 \%$ of dFv-LDPAE vs. $63.4 \%$ of LDM on hepatoma Bel-7402 in athymic mice $(\mathrm{P}<0.01)$. Small animal optical imaging showed that the FITC-labeled dFv-LDP preferentially localized in the tumor site in less than $30 \mathrm{~min}$, which demonstrated remarkable tumor-targeting properties. Taken together with the above findings, the enediyne-energized fusion protein $\mathrm{dFv}$-LDP-AE showed potential application as a new agent for therapeutic appications in $\mathrm{HCC}$.
\end{abstract}

Correspondence to: Dr Yong-Su Zhen, Institute of Medicinal Biotechnology, Chinese Academy of Medical Sciences and Peking Union Medical College, \#1 Tiantan Xili, Beijing 100050, P.R. China E-mail: zhenys@public.bta.net.cn

Key words: gelatinase, lidamycin, scFv, hepatocellular carcinoma, optical imaging

\section{Introduction}

Hepatocellular carcinoma (HCC) is one of the most common malignancies in the whole world. Each year more than 360,000 new cases are diagnosed with $\mathrm{HCC}$ in China and the incidence is continuing to rise (1). It is known that surgical resection is the primary curative treatment for HCC in clinic, however, the major treatment of patients with unresectable or metastatic hepatocellular carcinoma (HCC) is chemotherapy (2). Though numerous patients with HCC could be successfully induced into first remission by chemotherapy, most of them ultimately experienced a relapse within 3-5 years. In addition, chemotherapy is often accompanied with substantial side effects for the reason of non-specific cytotoxicity. Therefore, it is imperative to develop novel or other therapy approaches or agents for clinical HCC therapy. Targeted therapy by antibody-mediated therapy has emerged as a novel approach for the effective and innovative treatment of $\operatorname{HCC}(3,4)$.

Gelatinase (including matrix metalloproteinase (MMP)-2 and MMP-9), a member of MMPs, plays an important role in tumor growth and metastasis, and overexpression of these molecules is strongly correlated with poor prognosis in a variety of malignant tumors $(5,6)$. It is known that the gelatinases are abundantly presented in certain hepatocellular carcinoma $(7,8)$, therefore, gelatinases is a possible target for cancer therapy or cancer interference. Antibody targeting therapy of hepatoma is a new approach. To augment the antitumor efficiency, a potent cytotoxic drug conjugated with antibody has been attempted and already obtained distinct clinical outcome (9).

The enediyne family of antibiotics is among the most toxic antitumor compounds described to date (10). Lidamycin (LDM, also called C-1027) is an enediyne antibiotic with potent cytotoxicity causing DNA strand breaks at very low concentration (11). Therefore, lidamycin is a potential moiety or 'warhead' to conjugate with the antibody. It has been documented that antibody-lidamycin conjugate showed very good antitumor efficacy in vitro and in vivo (12-14). Our previous results demonstrated that a tandem $\mathrm{scFv}$ format conjugated with lidamycin (dFv-LDP-AE) improved the antitumor efficacy compared with the $\mathrm{scFv}$-lidamycin conjugate, and showed excellent tumor targeting capability to certain 
tumor cell lines, which indicated that the dFv-LDP-AE is a promising anticancer agent for development (15). As HCC is a leading cause of cancer death in China, developing new therapeutic strategies is warranted.

In this study, we observed the potential application of the tandem scFv-LDM conjugate (dFv-LDP-AE) in HCC. To evaluate the antitumor efficacy of dFv-LDP-AE, ELISA, immunofluorescene, cell cycle arrest and apoptosis experiments were performed, the inhibition of tumor growth and the targeting capability in vivo was also investigated.

\section{Materials and methods}

Materials. The preparation of the $\mathrm{dFV}$-LDP fusion protein and its enediyne-energized product $\mathrm{dFv}$-LDP-AE were described in our previous report (15). MTT and FITC were purchased from Sigma Chemical Co. (USA). Other chemical agents used were of analytical grade.

Cell culture. Human hepatoma Bel-7402 cells, and HepG 2 cells were stored in our lab and cultured at $37^{\circ} \mathrm{C}$ in DMEM medium supplemented with $10 \%$ fetal bovine serum, penicillin $\mathrm{G}(100 \mathrm{U} / \mathrm{ml})$ and streptomycin $(100 \mu \mathrm{g} / \mathrm{ml})$. All cell lines were passaged every 3 days and maintained in exponential growth to $\sim 80 \%$ confluence for experiments.

Binding specificity of $d F v-L D P$ with cancer cells by immunofluorescence. The human hepatoma Bel-7402 cells were grown on slides and fixed with ice-cold $70 \%$ methanol for $30 \mathrm{~min}$ at $4^{\circ} \mathrm{C}$. Non-specific binding was blocked with $3 \%$ BSA-PBS. After washing with PBS, the cells were incubated with dFv-LDP. The cells were then overlaid with mouse anti-His-Tag monoclonal antibodies after being washed with PBS. Then, the slides were mounted with fluorescein isothiocyanate (FITC)-conjugated goat anti-mouse antibody and then re-stained with propidium iodide (PI). Following a final washing step with PBS, the fluorescence images were captured by a fluorescence microscope.

Binding affinity assay. To quantitatively determine the binding affinity of fusion protein $\mathrm{dFv}$-LDP to hepatoma cells, the cellbased ELISA was used. Briefly, serial dilutions of re-folded $\mathrm{dFv}$-LDP or Fv-LDP in 1\% BSA-PBS were added into Bel-7402 and HepG 2 tumor cells in pre-coated plates, incubated and washed. Then, the plate was incubated with anti-His-tag HRP-conjugate and washed, 3,3',5,5'-tetramethylbenzidine was used as the chromogen for the color development, absorbance values at $450 \mathrm{~nm}$ were measured on microplate reader (Bio-Rad Laboratories).

MTT assay. Cells were detached by trypsinization, seeded at 3,000 cells/well in a 96-well plate (Costar, Cambridge, MA) overnight. Then different concentrations of LDM were added and incubated for an additional $48 \mathrm{~h}$. The effect on cell growth was examined by MTT assay. Briefly, $20 \mu \mathrm{l}$ of MTT solution $(5 \mathrm{mg} / \mathrm{ml})$ was added to each well and incubated at $37^{\circ} \mathrm{C}$ for $4 \mathrm{~h}$. The supernatant was removed, and the MTT formazan formed by metabolically viable cells was dissolved in $150 \mu \mathrm{l}$ of DMSO, and then monitored with a microplate reader (BioRad Labortories) at a wavelength of $570 \mathrm{~nm}$. Survival ratio was calculated according to the following formula: Survival ratio $=\left(\mathrm{A}_{\text {test }}-\mathrm{A}_{\text {blank }}\right) /\left(\mathrm{A}_{\text {control }}-\mathrm{A}_{\text {blank }}\right) \times 100 \%$.

Cell cycle analysis. Cells were treated with dFv-LDP-AE ( 0.01 and $0.1 \mathrm{nM})$ up to $48 \mathrm{~h}$. Floating and adherent cells were harvested and centrifuged at $500 \mathrm{x} \mathrm{g}$ for $5 \mathrm{~min}$. Then cells were fixed in ice-cold $70 \%$ ethanol and stored at $-20^{\circ} \mathrm{C}$ for $24 \mathrm{~h}$ before analysis. For cell cycle analysis, cells were washed twice in PBS and stained with $50 \mathrm{mg} / \mathrm{ml}$ propidium iodide and $200 \mu \mathrm{g} / \mathrm{ml} \mathrm{RNase} \mathrm{A}$ for $30 \mathrm{~min}$. The samples were analyzed on a fluorescence-activated cell sorter (Becton-Dickinson).

FITC-Annexin V/PI apoptosis assay. Cells were collected and resuspended in $200 \mu \mathrm{l}$ binding buffer. Then $10 \mu \mathrm{l}$ FITC-labeled enhanced Annexin V and $100 \mathrm{ng}$ propidium iodide were added. Upon incubation in the dark (15 min, room temperature or $30 \mathrm{~min}$ at $4^{\circ} \mathrm{C}$ ), the samples were diluted with $500 \mu \mathrm{l}$ binding buffer. Flow cytometry was carried out on a FACScan instrument (Becton-Dickinson) and data were processed by WinMDI/PC-software.

In vivo antitumor experiments. The antitumor experiments were carried out using two hepatoma cancer cell lines, the mouse hepatoma 22 (H22) and human hepatoma Bel-7402. Kunming (KM) mice and the male athymic nude mice (Balb/c $\mathrm{nu} / \mathrm{nu}$ ) were purchased from the institute of animal research, Chinese academy of medical science, and allowed to acclimatize in the institutional animal house for $>5$ days before use. The study protocols were in accordance with the regulations of Good Laboratory Practice for non-clinical laboratory studies of drugs issued by the National Scientific and Technologic Committee of People's Republic of China.

The mouse H22 animal experiment was performed with 7-week-old female Kunming mice. H22 cells suspended in saline were inoculated subcutaneously (Day 0) at the right axilla of the mouse with $1.5 \times 10^{6}$ cells $/ 0.2 \mathrm{ml} / \mathrm{mouse}$. The mice were randomized into seven groups with 10 mice in each group. On Day 2, dFv-LDP-AE was administered at doses of 0.75, 1.0 and $1.25 \mathrm{mg} / \mathrm{kg}$ of body weight. LDM, and $\mathrm{dFv}$-LDP fusion protein was administered at doses of 0.06 , and $1.25 \mathrm{mg} / \mathrm{kg}$, respectively. All treatments were administered by intravenous injection into the tail vein in $0.2 \mathrm{ml}$ of sterile PBS.

To further evaluate the antitumor efficacy of dFv-LDPAE, a second animal experiment was performed with 16-18-week-old nude mice. Exponentially growing human hepatoma Bel-7402 cells were implanted into two male athymic nude mice by the subcutaneous injection of $5 \times 10^{6}$ cells on the right flank. Tumors resulting after 2 weeks in donor animals were aseptically dissected and mechanically minced. Pieces of tumor tissue $\left(2 \mathrm{~mm}^{3}\right.$ in size) were transplanted (subcutaneously) by a trocar needle into nude mice. When tumors reached about $100 \mathrm{mg}$ in size, the mice were randomized into treatment groups ( $n=6$ per group). Then the treatments were started (intravenously injection twice approximately on Day 7 and 14 after tumor implantation), the nude mice were injected in the tail vein with $\mathrm{dFv}$-LDP-AE at different doses $(0.4,0.6$ and $0.8 \mathrm{mg} / \mathrm{kg})$, and with LDM $(0.05 \mathrm{mg} / \mathrm{kg}), \mathrm{dFv}-\mathrm{LDP}(0.8 \mathrm{mg} / \mathrm{kg})$, respectively. Control nude mice were injected with saline. Tumor growth was measured with a caliper, and tumor volumes were calculated 


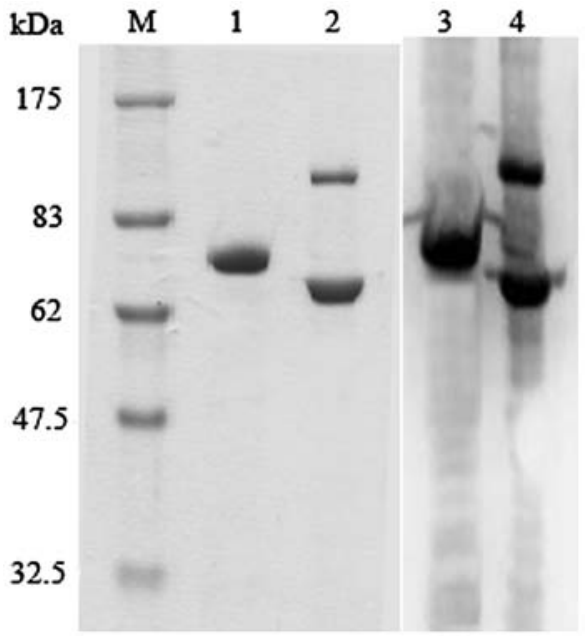

Figure 1. The SDS-PAGE electrophoretogram of dFv-LDP fusion protein under reduced (lane 1) and non-reduced (lane 2) conditions. M, the protein marker; lanes 3 and 4, the western blot results of lanes 1 and 2, respectively.

with the following formula: $\mathrm{V}=0.5 \mathrm{a} \times \mathrm{b}^{2}$, where $\mathrm{a}$ and $\mathrm{b}$ are the long and the perpendicular short diameters of the tumor, respectively (15). The data are presented as the mean \pm SD. Tumor growth curves were plotted of time against the mean tumor volume \pm SD.

The inhibitory rates of tumor growth were calculated according to the weight of excised tumor. The Student's t-test was used to determine statistically significant differences. $\mathrm{P}<0.05$ was considered significant.

Fluorescein isothiocyanate (FITC) labeling of the dFv-LDP and the small animal optical imaging. FITC were purchased from Sigma and was dissolved in dimethylsulfoxide. The protein $\mathrm{dFv}$-LDP was dialyzed against $0.1 \mathrm{M}$ sodium bicarbonate $(\mathrm{pH} 9.6)$ three times. Then the protein and FITC solutions were mixed in a final volume of $2.5 \mathrm{ml}$ and incubated for $8 \mathrm{~h}$ at $4^{\circ} \mathrm{C}$ in the dark with constant shaking, after that $25 \mu \mathrm{l}$ ammonium chloride $(5 \mathrm{~mol} / \mathrm{l})$ was added to terminate the reaction for another $2 \mathrm{~h}$. The FITC-labeled dFv-LDP were separated from free FITC on a Sephadex G-25 column equilibrated with phosphate-buffered saline (PBS). The protein-FITC ratio was measured with the formula $3.1 \times$ A495/(A280 - $0.31 \times$ A495) and the concentration of labeled protein was determined by the formula (A280 - 0.31 x A495)/1.4 (16). The small animal optical imaging was performed with an IVIS Imaging System (Xenogen) comprised of a highly sensitive, cooled CCD camera mounted in a light-tight specimen box. Images and measurements of fluorescence signals were acquired and analyzed using Living Image software (Xenogen). Ten to $15 \mathrm{~min}$ prior to in vivo imaging, animals received the FITC-labeled dFv-LDP at $40 \mathrm{mg} / \mathrm{kg}$ by tail vein and were anesthetized using 1-3\% isoflurane. Animals were placed onto the warmed stage inside the camera box and received continuous exposure to $1-2 \%$ isoflurane to sustain sedation during imaging. The imaging time was $20 \mathrm{sec}$ and two to three mice were imaged at a time. The light emitted from the FITC was detected in vivo by the IVIS Imaging System, digitized and electronically displayed as a pseudocolor overlay onto a gray scale animal image.

Statistical analysis. Significant difference between two values was determined with the Student's t-test. $\mathrm{P}<0.05$ was considered statistically significant.

\section{Results}

The preparation of $d F v$-LDP fusion protein. The fusion protein $\mathrm{dFv}$-LDP was produced by $E$. coli and expressed mainly as inclusion body. After purification and refolding as reported previously (15). In this study, the PAGE was used to analyze the fusion protein $\mathrm{dFv}$-LDP under reduced and nonreduced conditions. As shown in Fig. 1, there is a tiny band under the non-reduced condition, which indicates that a small percent of $d F v-L D P$ exists as a dimer.

Binding capability with tumor cells. To investigate the binding of fusion protein $\mathrm{dFv}$-LDP with HCC, enzyme-linked immunosorbent assay (ELISA) was used to determine the affinity of dFv-LDP with Bel-7402 and HepG 2 cell lines. As shown in Fig. 2, fusion protein dFv-LDP could bind with tumor cells in a dose-dependent and saturable manner (Fig. 2), and the affinity constant is about 2- or 3-fold increased compared to the Fv-LDP, which contained just a single scFv. The binding of dFv-LDP with tumor cells was also displayed by immunofluorescence, as shown in Fig. 3, which indicated that the
A

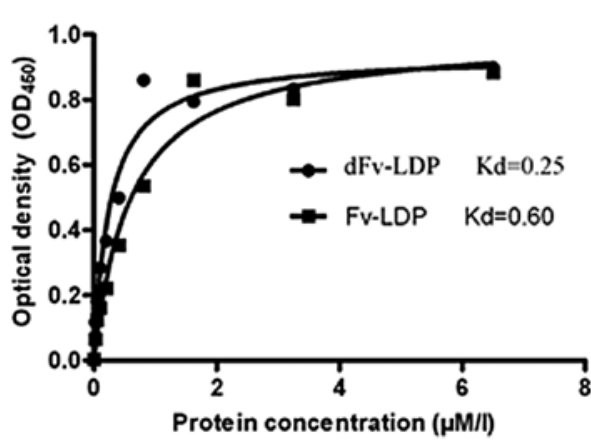

B

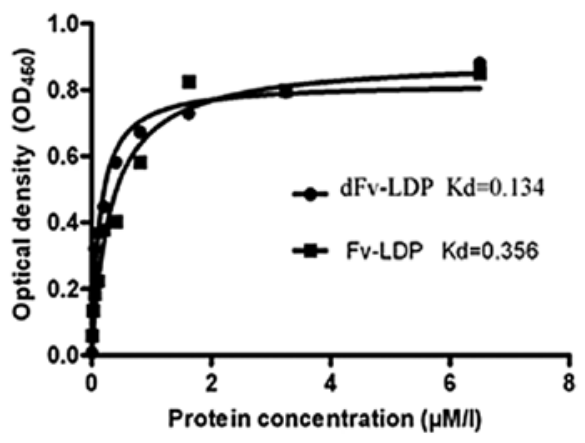

Figure 2. The affinity determination of fusion protein dFv-LDP and Fv-LDP with hepatoma Bel-7402 (A) and HepG 2 (B) cell lines by ELISA. 
A

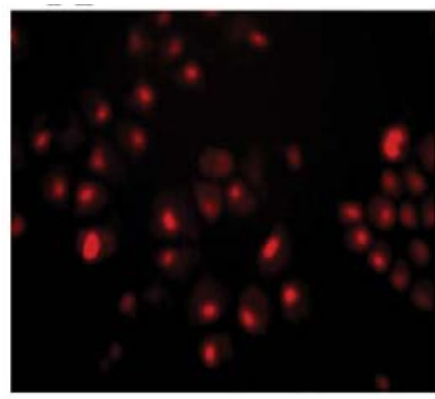

B

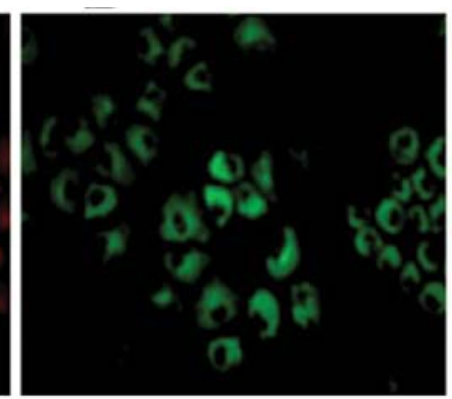

C

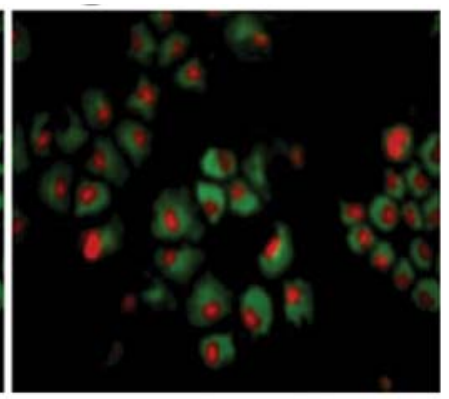

Figure 3. The immunofluorescence analysis of fusion protein dFv-LDP with Bel-7402 cancer cells. (A) The phase contrast stained with PI, (B) the green fluorescene of FITC and (C) the merge of (A and B). Original magnification, x200.

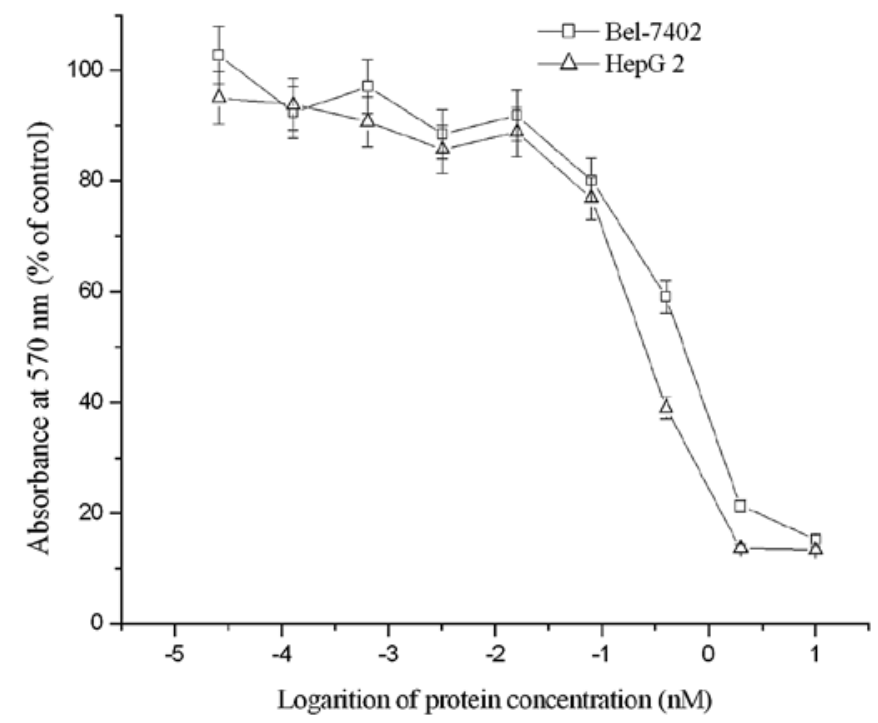

Figure 4. The cytotoxicity of energized fusion protein dFv-LDP-AE to Bel7402 and HepG 2 cells using MTT assay.

gelatinases are abundantly expressed around the tumor cells, and the fusion protein $\mathrm{dFv}$-LDP could efficiently bind them.

Ctytotoxicity of $d F v-L D P-A E$ in vitro. As examined by MTT assay, the enediyne-energized fusion protein $\mathrm{dFv}$-LDP-AE displayed potent cytotoxicity to two HCC cell lines. As shown in Fig. 4, the $\mathrm{IC}_{50}$ of dFv-LDP-AE to Bel-7402 and HepG 2 tumor cells were $\sim 4.5 \times 10^{-10} \mathrm{M}$ and $7.7 \times 10^{-10} \mathrm{M}$, respectively.

Cell cycle analysis. HepG 2 and Bel-7402 tumor cells were PI stained and the cell cycle progression was evaluated using flow cytometry. As shown in Fig. 5, an apparent increase of cells in the G2 phase by $3.06-68.71 \%$ with a corresponding decrease of cells in the G1 phases, was observed in Bel-7402 cells upon treatment with $0.01 \mathrm{nM}$ and $0.1 \mathrm{nM} \mathrm{dFv}-\mathrm{LDP}$ AE. Similarly, an increase of cells arrest in G2 phase by $7.4-49.26 \%$ with a corresponding decrease of cells in the G1 phase was detected in HepG 2 cells after exposure to $\mathrm{dFv}-\mathrm{LDP}-\mathrm{AE}$ at indicated doses, thus, indicating that $\mathrm{dFv}$ LDP-AE had potent inhibition on the progression of HCC tumor cells.
Apoptosis analysis. FITC-Annexin V/PI analysis showed that the energized fusion protein $\mathrm{dFv}$-LDP-AE induced apoptosis in Bel-7402 and HepG 2 cells. As shown in Fig. 6, 0.01 and $0.1 \mu \mathrm{M} \mathrm{dFv-LDP}-\mathrm{AE}$ induced apoptosis in 15.48 and $34.7 \%$ of Bel-7402 cells, respectively. Similarly, 0.01 and $0.1 \mu \mathrm{M} \mathrm{dFv-}$ LDP-AE resulted in apoptosis in 9.9 and $35.16 \%$ of HepG 2 cells, respectively.

The antitumor effect of $d F v-L D P-A E$ in vivo. The in vivo antitumor effects of $\mathrm{dFv}$-LDP-AE were investigated on the inhibition of subcutaneously transplanted murine $\mathrm{H} 22$ in Kunming mice. The tumor-bearing mice were treated by tail vein injection once at $48 \mathrm{~h}$ after transplantation. The results showed that dFv-LDP-AE significantly inhibited the growth of hepatoma 22 tumors (Table I). As evaluated on Day 12, $\mathrm{dFv}$-LDP-AE at $1.25,1.0$ and $0.75 \mathrm{mg} / \mathrm{kg}$ suppressed the tumor growth by $89.5 \%$ ( $\mathrm{P}<0.05$ vs. $\mathrm{LDM}$ ), $85.2 \%$ ( $\mathrm{P}<0.01$ vs. control) and $77.4 \%$ ( $\mathrm{P}<0.01$ vs. control), respectively, whereas the free LDM at tolerated dose of $0.06 \mathrm{mg} / \mathrm{kg}$ showed an inhibition rate of $73.6 \%$ and the 'naked' fusion protein $\mathrm{dFv}-\mathrm{LDP}$ at $1.25 \mathrm{mg} / \mathrm{kg}$ also showed a moderate inhibition rate $(37.6 \%)$ on tumor growth. During the whole experiment, all treated mice survived at the final time, no severe side-effects were observed during the treatment and the body weight of the mice had increased a little.

The antitumor activities of dFv-LDP-AE were also evaluated in nude mice with xenograft of Bel-7402 human hepatoma. When the tumors reached about $100 \mathrm{~mm}^{3}$ in size, the mice were randomized into 6 treatment groups $(n=6$ per group). The treatments were started by intravenously injection twice approximately on Day 7 and 14 after tumor implantation. As shown in Fig. 7A, Bel-7402 xenografts grew rapidly in nude mice, and the tumor volume in the control group increased from 22 to $1522 \mathrm{~mm}^{3}$ (around 70-fold increase) over 31 days duration of the experiment. Mice treated with LDM at the tolerated dose of $0.05 \mathrm{mg} / \mathrm{kg}$ showed an inhibition rate of $63.4 \%$. $\mathrm{dFv}$-LDP-AE at $0.8 \mathrm{mg} / \mathrm{kg}$ suppressed the tumor growth by $87.3 \%$, which demonstrated statistically significant differences $(\mathrm{P}<0.01)$ compared with that of LDM at $0.05 \mathrm{mg} / \mathrm{kg}$. The therapeutic efficacy in groups of $\mathrm{dFV}$ LDP-AE was dose-dependent. The fusion protein $\mathrm{dFV}$-LDP $(0.8 \mathrm{mg} / \mathrm{kg})$ also showed certain therapeutic efficacy (around $38.8 \%$ inhibition). These results suggested that dFv-LDP-AE could inhibit the growth of Bel-7402 xenografts significantly 

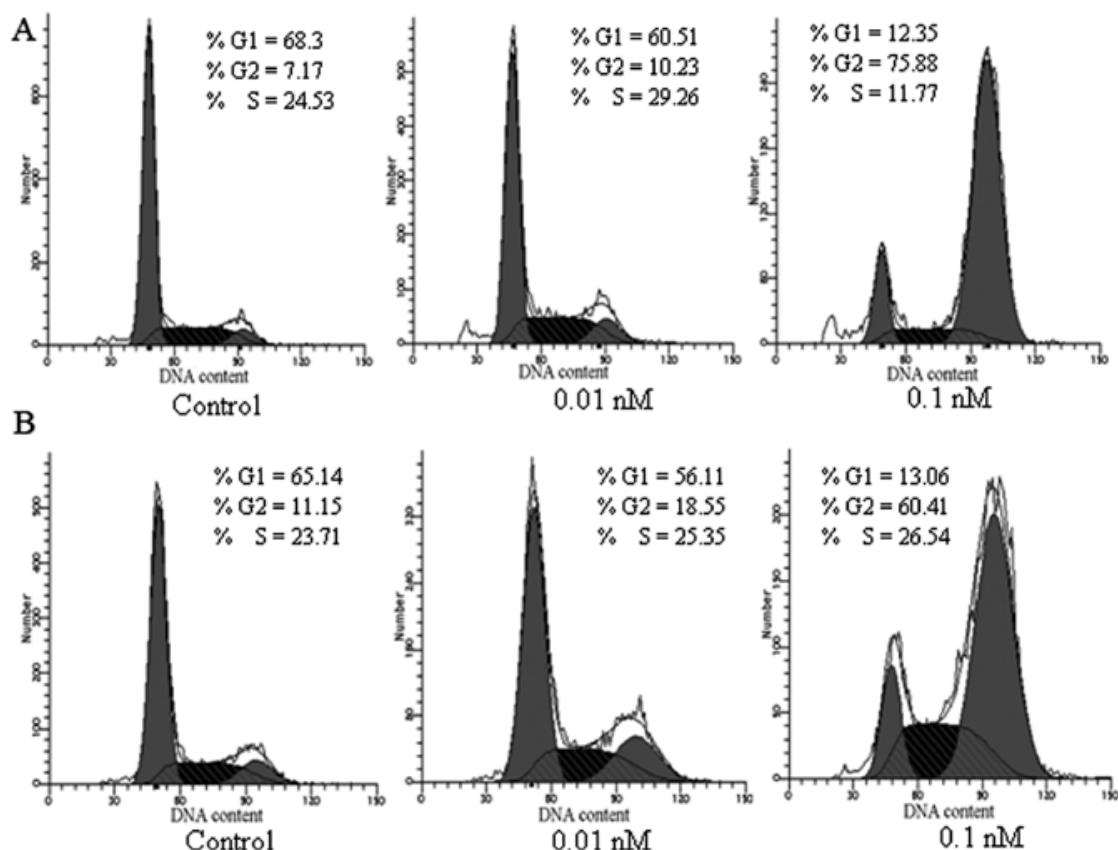

Figure 5. Cell cycle analysis of cells treated with dFv-LDP-AE. Bel-7402 cells and HepG 2 cells were stained with PI after a 48 -h exposure to 0.01 and $0.1 \mathrm{nM}$ dFv-LDP-AE. Percentages of the total cell population in the different phases of the cell cycle were determined. Representative results of experiment are shown.
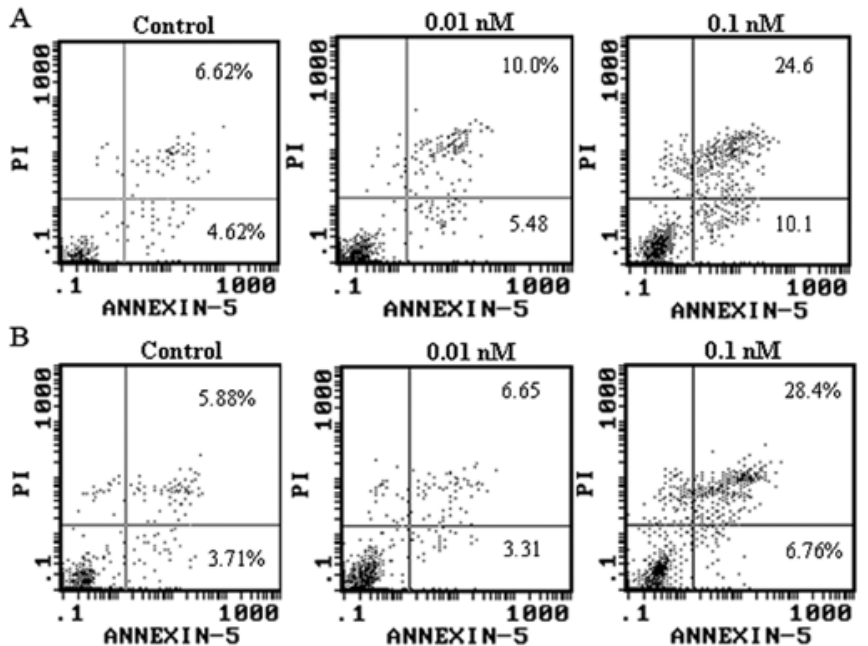

Figure 6. Apoptosis induced by dFv-LDP-AE. Cells were cultured for $48 \mathrm{~h}$ with control medium, or with 0.01 and $0.1 \mathrm{nM}$ dFv-LDP-AE, respectively. Cells were then harvested and labeled with a combination of Annexin V-FITC and propidium iodide. The percentage of early apoptotic cells (lower right quadrant) and late apoptotic/necrotic cells (upper right quadrant) is indicated.

Table I. Tumor growth inhibition effects of dFv-LDP-AE on hepatoma 22 in mice.

\begin{tabular}{lccccc}
\hline Groups & $\begin{array}{c}\text { Dose } \\
(\mathrm{mg} / \mathrm{kg})\end{array}$ & $\begin{array}{c}\text { Mouse no. } \\
\text { (begin/end) }\end{array}$ & $\begin{array}{c}\mathrm{BWC} \\
(\text { mean } \pm \mathrm{SD}, \mathrm{g})\end{array}$ & $\begin{array}{c}\text { Tumor weight } \\
(\text { mean } \pm \mathrm{SD}, \mathrm{g})\end{array}$ & Inhibition ratio (\%) \\
\hline Control & & $10 / 10$ & $11.632 \pm 0.95$ & $3.1 \pm 0.36$ & - \\
LDM & 0.06 & $10 / 10$ & $3.57 \pm 2.48$ & $0.82 \pm 0.61$ & $73.6^{\mathrm{a}}$ \\
dFv-LDP-AE & 0.75 & $10 / 10$ & $3.28 \pm 1.46$ & $0.7 \pm 0.44$ & $77.4^{\mathrm{a}}$ \\
& 1.0 & $10 / 10$ & $3.36 \pm 1.24$ & $0.46 \pm 0.32$ & $85.2^{\mathrm{a}}$ \\
& 1.25 & $10 / 10$ & $2.79 \pm 2.47$ & $0.33 \pm 0.21$ & $89.5^{\mathrm{a}, \mathrm{b}}$ \\
dFv-LDP & 1.25 & $10 / 10$ & $10.56 \pm 2.17$ & $1.93 \pm 0.70$ & 37.6 \\
\hline
\end{tabular}

${ }^{\mathrm{a} C}$ Compared to the control, $\mathrm{P}<0.05 ;{ }^{\mathrm{b}}$ compared to LDM, $\mathrm{P}<0.05$. 

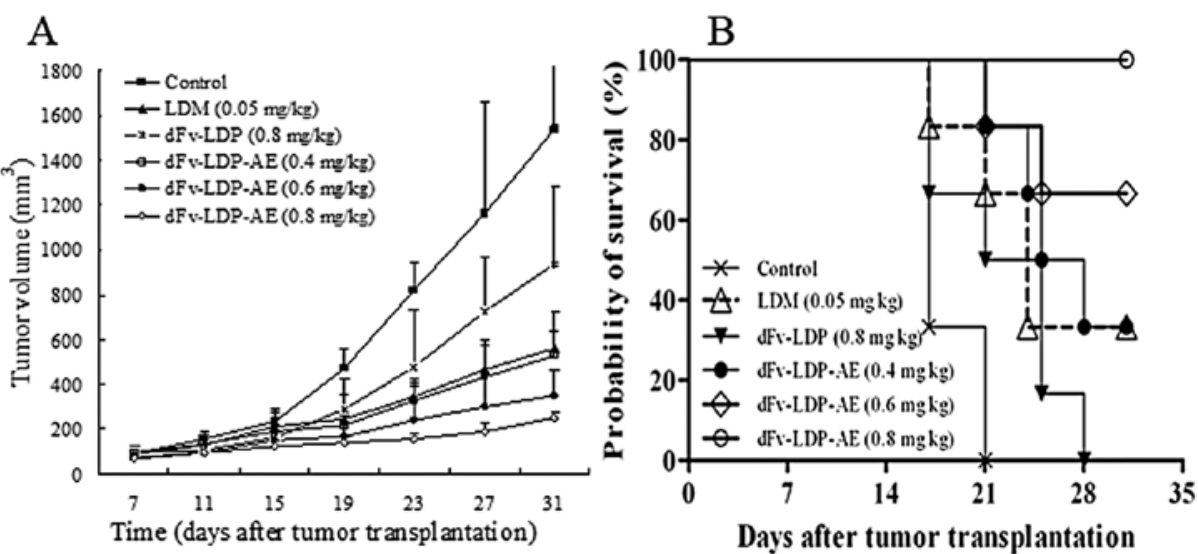

Figure 7. Antitumor activities of dFv-LDP alone or enediyne-energized dFv-LDP-AE on Bel-7402 xenografts. Numbers in parentheses represent dosages at $\mathrm{mg} / \mathrm{kg}$. (A) The tumor growth curves in 31-day duration of experiments. Data are expressed as mean tumor volume \pm SD (n=6). (B) The Kaplan-Meier survival curve (end-points defined as tumor load of $400 \mathrm{~mm}^{3}$ ) demonstrated that compared with other groups, probability of survival (i.e., probability of maintaining a tumor volume $\left.<400 \mathrm{~mm}^{3}\right)$ of mice treated with $\mathrm{dFv}$-LDP-AE was significantly improved $(\mathrm{P}<0.05)$.
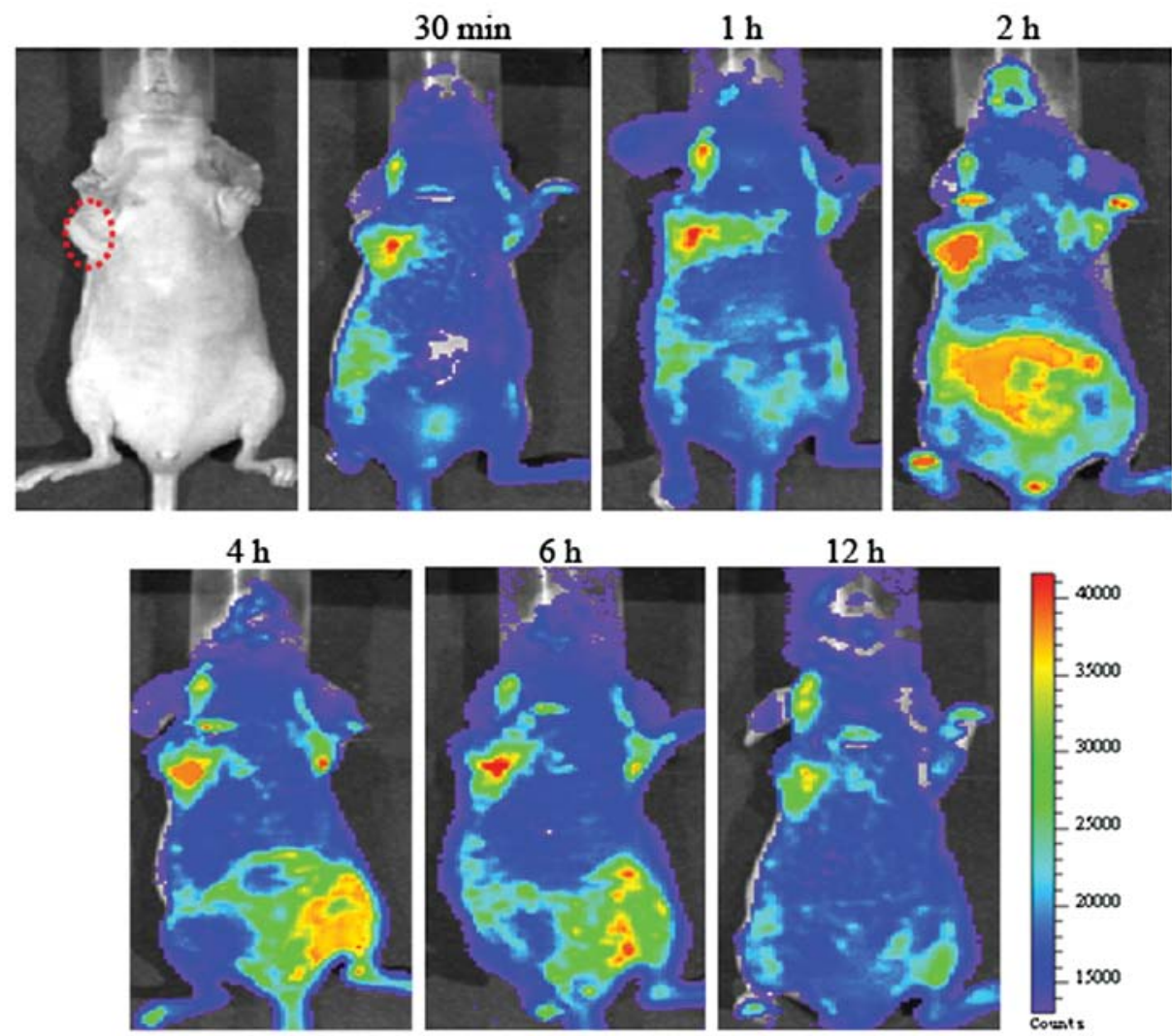

Figure 8. Optical imaging in nude mice bearing right flank subcutaneous Bel-7402 tumor using FITC-labeled dFv-LDP. Color scale represents photons/s/cm²/ steradian, the red dot-cycle indicates the tumor location. The imaging was performed at $30 \mathrm{~min}, 1,2,4,6$ and $12 \mathrm{~h}$ after intravenous injection with FITC-labeled $\mathrm{dFv}-\mathrm{LDP}$ at a dosage of $40 \mathrm{mg} / \mathrm{kg}$.

in nude mice; and the therapeutic efficacy of dFv-LDP-AE was apparently stronger than that of LDM $(\mathrm{P}<0.01)$, as compared under the tolerable dosage. i.e. the targeting delivery of LDM by an anti-gelatinase antibody fragment enhanced the antitumor effects significantly. It was also noteworthy that the enediyne-energized fusion protein $\mathrm{dFv}$-LDP-AE was shown to be significantly more effective than $\mathrm{dFv}$-LDP or LDM used alone in prolonging the survival of mice $(\mathrm{P}<0.05$, Fig. 7B).
The small animal optical imaging using FITC-labeled fusion protein. We previously reported the tumor targeting capability of $\mathrm{dFv}$-LDP to certain tumor cells and the injection dose was $20 \mathrm{mg} / \mathrm{kg}$. As the FITC is not a very good fluorescence in imaging in vivo (17), its wavelength is relatively short and it could not penetrate thick tissue, in order to make the in vivo imaging much more clear, the higher dose of $40 \mathrm{mg} / \mathrm{kg}$ FITClabeled fusion protein $\mathrm{dFv}$-LDP was injected via tail vein. As 
shown in Fig. 8, we observed significant tumor retention of FITC-labeled dFv-LDP in the tumor foci, the FITC-labeled dFv-LDP saturated the tumor and its surrounding sites within $30 \mathrm{~min}$ after injection. The signal of fluorescence was still visible at the tumor site and maintaining the signal at $12 \mathrm{~h}$ after administration. As we expected, the dFv-LDP demonstrated very good tumor targeting potential, which was mainly located at tumor sites. However, the question regarding

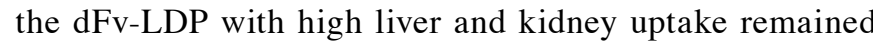
unsolved, therefore causing a problem in the systemic toxicity to normal organs.

\section{Discussion}

In this study, we demonstrate that the tandem anti-gelatinase $\mathrm{ScFV}$ format improved the biodistribution and therefore enhanced the antitumor effects of LDM. By covalent association of a tandem anti-gelatinase $\mathrm{scFv}$ to the $\mathrm{N}^{\prime}$ terminal of LDM, the accumulation of LDM in the peritumor tissue could be increased, and the tumor killing capability, the G2/M phase arrest or the induction of apoptosis would be greatly enhanced. Therefore, the inhibition rate of LDM and $\mathrm{dFV}$-LDP-AE on tumor growth is apparently improved from 73.6 to $89.5 \%$ in hepatoma 22 xenograft tumor model and from 63.4 to $87.3 \%$ in hepatoma Bel-7402 xenograft tumor model. The explanation for this difference is the tumor targeting ability of the tandem scFv format. From the results of the optical imaging, the degree and specificity of tumor localization were due to $\mathrm{dFv}$-LDP-AE, which was presumably as a result of its affinity with gelatinase overexpression in tumor sites.

Gelatinases are abundantly overexpressed in HCC and its stromal cells, and play an important role in tumor microenvironment $(18,19)$. In this study, it found that the 'naked' fusion protein $\mathrm{dFv}$-LDP had an inhibition rate of $38.8 \%$ at a dosage of $0.8 \mathrm{mg} / \mathrm{kg}$ in Bel-7402 xenograft, which indicated that the fusion protein $\mathrm{dFv}-\mathrm{LDP}$ not only played as a carrier of $\mathrm{AE}$, but also possessed certain antitumor efficacy in vivo. This might be attributed to the dual effects of dFv-LDP on tumor growth inhibition and the disturbed balance of tumor microenvironment.

In the small animal optical imaging experiment, the fast tumor location of dFv-LDP at $30 \mathrm{~min}$ after administration was observed. When accumulation of $\mathrm{dFv}$-LDP-AE in the target tissue is achieved, therapeutic efficacy is displayed by a potent tumor-killing power of $\mathrm{AE}$. The rapid accumulation of dFv-LDP-AE in tumor site indicated that the dFv-LDP-AE might not decompose or decay before being delivered to the target site. Thus, the dFv-LDP-AE effects could be internalization or display of a 'bystander' effect, killing nearby tumor cells in addition to the directly targeted cells.

In summary, in this study we demonstrated that the tandem format $\mathrm{dFv}$-LDP-AE showed improved antitumor effect and biodistribution compared to the LDM by increasing the targeting delivery of LDM indicating that the gelatinases (MMP-2 and MMP-9) are a valid target for antibody-directed therapy. Although, more studies are warranted to further explore targeting ability and decreasing the immunogenicity for the murine origin of the $\mathrm{scFv}$ used, as well as lowering the kidney and liver adsorption.

\section{Acknowledgements}

This research was supported by grants from 'Significant new drug development' Science and Technology Major Projects of China (2009ZX09301-003; 2009ZX09401-005; 2010ZX09401-407).

\section{References}

1. Chen JG and Zhang SW: Liver cancer epidemic in China: past, present and future. Semin Cancer Biol 21: 59-69, 2011.

2. Edeline J, Raoul JL, Vauleon E, Guillygomac'h A, Boudjema K and Boucher E: Systemic chemotherapy for hepatocellular carcinoma in non-cirrhotic liver: a retrospective study. World J Gastroenterol 15: 713-716, 2009.

3. Mohr L, Yeung A, Aloman C, Wittrup D and Wands JR: Antibody-directed therapy for human hepatocellular carcinoma. Gastroenterology 127: S225-S231, 2004.

4. Smith LM, Nesterova A, Ryan MC, et al: CD133/prominin-1 is a potential therapeutic target for antibody-drug conjugates in hepatocellular and gastric cancers. Br J Cancer 99: 100-109, 2008.

5. Bjorklund $\mathrm{M}$ and Koivunen E: Gelatinase-mediated migration and invasion of cancer cells. Biochim Biophys Acta 1755: 37-69, 2005.

6. Svagzdys S, Lesauskaite V, Pangonyte D, Saladzinskas Z Tamelis A and Pavalkis D: Matrix metalloproteinase-9 is prognostic marker to predict survival of patients who underwent surgery due to rectal carcinoma. Tohoku J Exp Med 223: 67-73, 2011.

7. Kim KR, Bae JS, Choi HN, et al: The role of serum response factor in hepatocellular carcinoma: an association with matrix metalloproteinase. Oncol Rep 26: 1567-1572, 2011.

8. Chen R, Cui J, Xu C, et al: The significane of MMP-9 over MMP-2 in HCC invasiveness and recurrence of hepatocellular carcinoma after curative resection. Ann Surg Oncol: Jun 17, 2011 (Epub ahead of print).

9. Alley SC, Okeley NM and Senter PD: Antibody-drug conjugates: targeted drug delivery for cancer. Curr Opin Chem Biol 14: $529-537,2010$.

10. Shao RG: Pharmacology and therapeutic applications of enediyne antitumor antibiotics. Curr Mol Pharmacol 1: 50-60, 2008.

11. Shao RG and Zhen YS: Enediyne anticancer antibiotic lidamycin: chemistry, biology and pharmacology. Anticancer Agents Med Chem 8: 121-131, 2008.

12. Guo XF, Zhu XF, Shang Y,Zhang SH and Zhen YS: A bispecific enediyne-energized fusion protein containing ligand-based and antibody-based oligopeptides against epidermal growth factor receptor and human epidermal growth factor receptor 2 shows potent antitumor activity. Clin Cancer Res 16: 2085-2094, 2010.

13. Xin C, Ye S, Ming Y, et al: Efficient inhibition of B-cell lymphoma xenografts with a novel recombinant fusion protein: anti-CD20Fab-LDM. Gene Ther 17: 1234-1243, 2010.

14. Zhang Q, Liu XJ, Hu L, et al: Factor VII light chain-targeted lidamycin targets tissue factor-overexpressing tumor cells for cancer therapy. Int J Mol Med 29: 409-415, 2012.

15. Zhong G, Zhang S, Li Y, Liu X, Gao R, Miao Q and Zhen Y: A tandem scFv-based fusion protein and its enediyne-energized analogue show intensified therapeutic efficacy against lung carcinoma xenograft in athymic mice. Cancer Lett 295: 124-133, 2010.

16. Zhang SH, Cheng X, Zhong GS, Xiong DS and Shao RG: In vivo imaging analysis of biodistribution of FITC-labeled Rituximab in lymphoma-bearing nude mice. Zhonghua Yi Xue Za Zhi 90: 2367-2370, 2010 (In Chinese).

17. Hama Y, Urano Y, Koyama Y, et al: In vivo spectral fluorescence imaging of submillimeter peritoneal cancer implants using a lectin-targeted optical agent. Neoplasia 8: 607-612, 2006.

18. Gerg M, Kopitz C, Schaten S, et al: Distinct functionality of tumor cell-derived gelatinases during formation of liver metastases. Mol Cancer Res 6: 341-351, 2008.

19. Määttä M, Soini Y, Liakka A and Autio-Harmainen H: Differential expression of matrix metalloproteinase (MMP)-2, MMP-9, and membrane type 1-MMP in hepatocellular and pancreatic adenocarcinoma: implications for tumor progression and clinical prognosis. Clin Cancer Res 6: 2726-2734, 2000 . 